\title{
The Association of Angiotensin-converting Enzyme I/D and Angiotensinogen M235T Polymorphism Genes with Essential Hypertension: A Meta-analysis
}

\author{
Agus Wibowo ${ }^{1}$ D, Pramudji Hastuti ${ }^{2 *}$ D , Vinayanti Susanti ${ }^{3}$ \\ ${ }^{1}$ Department of Biochemistry, Faculty of Medicine, Public Health and Nursing, Universitas Gadjah Mada, National Institute of \\ Health Research and Development, Indonesia Ministry of Health, Yogyakarta, Indonesia; ${ }^{2}$ Department of Biochemistry, Faculty \\ of Medicine, Public Health and Nursing, Universitas Gadjah Mada, Yogyakarta, Indonesia; ${ }^{3}$ Department of Internal Medicine \\ Faculty of Medicine, Public Health and Nursing, Universitas Gadjah Mada, Yogyakarta, Indonesia
}

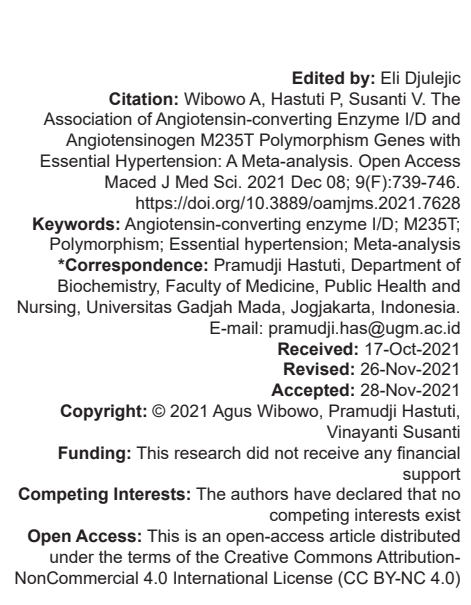

\section{Introduction}

Essential or primary hypertension is a treatable disease that involves complex interactions between environmental and genetic factors [1], [2]. In developing countries such as in Asia and Africa, essential hypertension affects $25 \%-35 \%$ of the adult population [3]. In the past decade, many genes have been associated with high blood pressure and hypertension. The most extensively studied candidate genes for essential hypertension are Reninangiotensin System (RAS) genes, which include angiotensinogen (AGT) and angiotensin-converting enzyme (ACE) genes [4]. Identified in the etiopathogenesis of hypertension, ACE is a key component of RAS [5].

The AGT gene is one of the major structural genes in the RAS pathway and it also regulates AGT expression, particularly the renin substrate. Research showed that the renin substrate is cleaved by renin into angiotensin I and then into vasoactive angiotensin II by ACE [6]. These two genes are the most prominent candidate genes being analyzed for their close association with the development of essential hypertension. However, in some populations, the results were inconclusive. Due to several limitations, the previous meta-analyses were not adequate to determine the actual correlation between ACE and AGT with hypertension because of its complex, multifactorial etiology, and the close but confusing links between Adrenoreceptor-beta/RAS (ADRB/RAS) polymorphisms and ethnicity.

Our present meta-analysis aimed to clarify the association between ACE I/D and AGT M235T gene polymorphisms and the risk of essential hypertension in populations from Asia to Africa, which have almost the same socio-economic conditions as other developing countries. Our meta-analysis results may be able to establish a clearer association in this topic. 


\section{Materials and Methods}

The PubMed, Embase.com, Medline, Google Scholar, Scopus.com, and Cochrane databases were used to retrieve all publications from 2006 to 2020 relating risk factors for hypertension and single ADRB/ ACE polymorphisms. The meta-analysis was conducted from January to April 2020. All association studies were identified and data extracted from each study. The first step in this study involved evaluating the quality of enrolled studies and extracting data. After that, software RevMan 5.3 was used for this meta-analysis to estimate odds ratios (OR). These publications were related to case-control and cross-sectional studies that reported a relation/link between the risk of essential hypertension and ADRB/ACE polymorphisms using the keywords: AGT AND ACE AND polymorphism AND blood pressure OR Hypertension AND Genetic AND Variation to retrieve the related documents. The document retrieval was limited to English-language articles (Figure 1).

\section{Inclusion criteria and data extraction}

\section{Inclusion criteria}

The following inclusion criteria were used in this meta-analysis: (1) The published articles reported studies of the correlation between ACE I/D or AGT M235T polymorphisms and incidence of essential hypertension; (2) the articles discussed crosssectional or case-control studies, where the control group included healthy or relatively healthy people without hypertension and the case group was patients with essential hypertension; (3) the articles provided studies of the frequency distribution of the ACE I/D or AGT M235T directly or indirectly in cases and control groups or in the cross-sectional study; (4) genetic polymorphisms of ACE I/D and AGT M235 T were in line with Hardy-Weinberg equilibrium (HWE) or not in equilibrium; and (5) hypertension was defined as the presence of systolic blood pressure measurement of at least $140 \mathrm{mmHg}$ and diastolic blood pressure measurement of at least $90 \mathrm{mmHg}$. In addition, for ACE and AGT genotypes, there were six ethnic groupings, either from Asia or from Africa (Table 1).

Two investigators (P.H and V.Y.S) extracted data independently and if there were differences, the consensus was reached by discussing or consulting a third party. The following contents were extracted from the studies: The first author's name, year of publication, ethnicity (Asia or Africa) of the study population, the characteristics of each group in cases and controls or cross-sectional study, the genotyping method, controls' source, and sample sizes of cases and controls or crosssectional study. The allele frequencies and genotypic distributions in both cases and controls or crosssectional study were calculated. In addition, the HWE status in each group was tested for this study (Table 1).

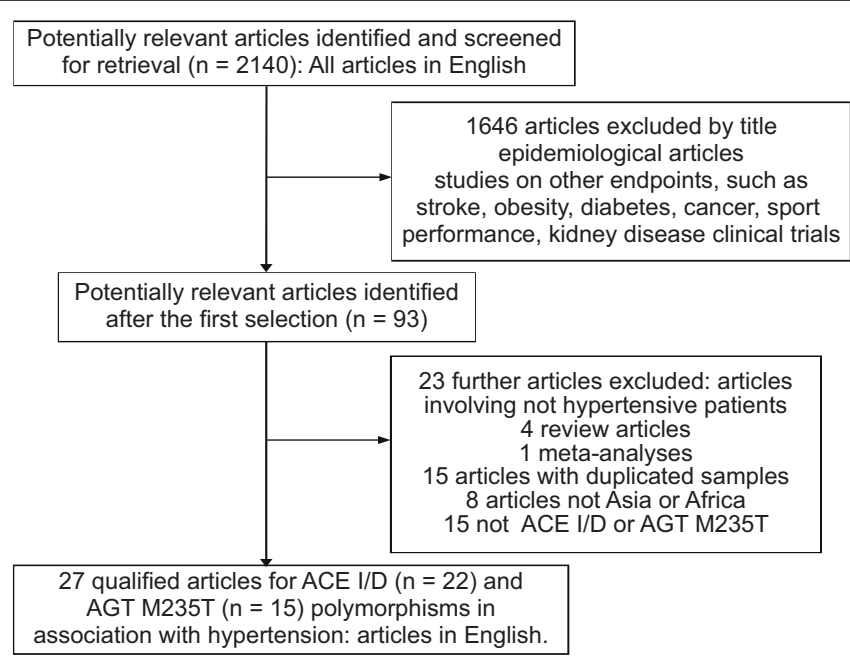

Figure 1: Flowchart of eligibility pathway in our study

\section{Exclusion criteria}

Articles were excluded if the literature did not provide valid data, was duplicated, or the full text could not be obtained.

\section{Statistical analysis}

The pooled OR was calculated to estimate the association between AGT/ACE polymorphisms and essential hypertension and its associated 95\% confidence interval $(\mathrm{Cl})$. The pooled $\mathrm{OR}$ was determined through a Z-test $(p<0.05)$. Heterogeneity was detected by $Q$ test; if an article had an absence of heterogeneity $\left(\mathrm{I}^{2}<50 \%\right)$, the Mantel-Haenszel method was used to calculate pooled OR and $95 \%$ Cis/fixed effect. A randomeffect model was used in meta-analysis when $\mathrm{I}^{2}$ was greater than $50 \%$. RevMan 5.3 software was used to conduct all analysis in this study. As a visual aid, a funnel plot was used to investigate the publications and possible types of bias. The forest plot was used to show the characteristics of the various findings.

\section{Results}

\section{Data synthesis}

A total of 27 studies consisting of 22 articles concerning ACE I/D and 15 articles discussing AGT M235T were included in our analysis. The cumulative genotype percentages for DD, ID, and II for ACE were $31.5 \%, 43.2 \%$, and $2.3 \%$, respectively, and for AGT, there were MM 28.8\%, MT 37.7\%, and TT $33.6 \%$, while in the control group, the percentages were $26.9 \%$, $42.2 \%$, and $30.9 \%$ for DD, ID, and II, respectively, and MM 33.3\%, MT 36.7\%, and TT 33.0\%. Overall, our analysis found that the $\mathrm{D}$ allele (OR: $95 \% \mathrm{Cl}=1.51$ [1.29-1.77], $p<0.00001$ ) (Figure 2a) and DD genotype (OR: $95 \% \mathrm{Cl}=1.54$ [1.15-2.06], $\mathrm{p}=0.004$ ) were 


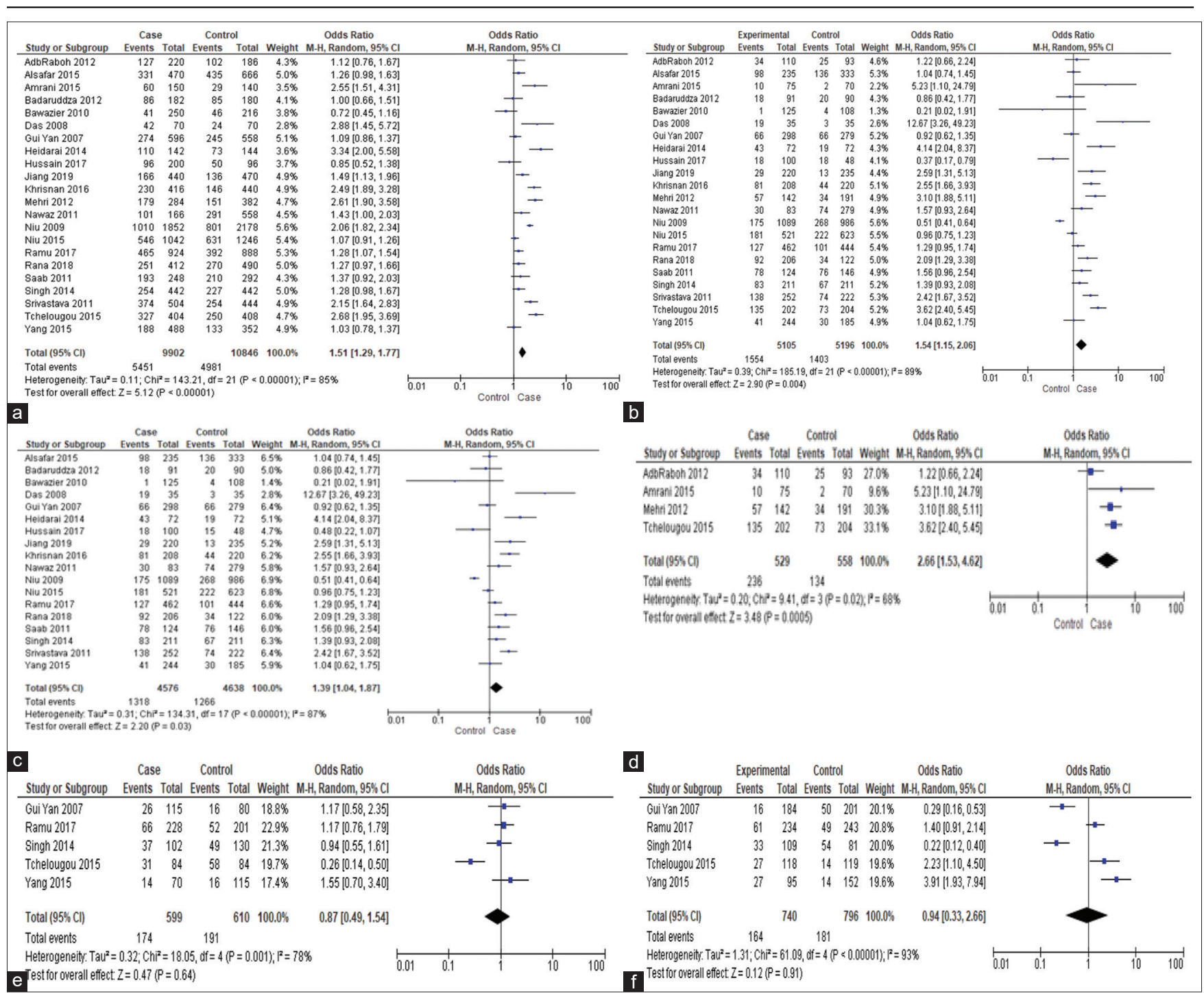

Figure 2: Forest plot for association between angiotensin-converting enzyme I/D gene polymorphism and the risk of essential hypertension: (a) $D$ versus I; (b) DD versus ID + II); (c) Asian sub-group DD versus ID + II; (d) African sub-group DD versus ID + II; (e) Male gender sub-group $D D$ versus ID + II; and (f) Female gender sub-group DD vs. ID + II

significantly associated with increased risk of essential hypertension (Figure 2b) but the TT allele (OR: 95\% $\mathrm{Cl}=1.03$ [0.74-1.43], $\mathrm{p}=0.86$ ) (Figure $3 \mathrm{~b}$ ) and $\mathrm{T}$ allele (OR: $95 \% \mathrm{Cl}=1.20$ [0.90-1.61], $\mathrm{p}=0.22$ ) were not associated with essential hypertension (Figure 3a). To establish a comprehensive analysis, we also performed a sub-group analysis according to the continent of origin and gender. Continent sub-group analysis consisted of Asian and African sub-groups.

In the Asian sub-group analysis, the genotype percentages were DD $28.0 \%$, ID $45.4 \%$, and II $26.6 \%$ and for MM, MT, and TT in patients with essential hypertension, there were $25.5 \%, 38.0 \%$, and $36.3 \%$, respectively. Meanwhile, in the control group, the percentages were $25.1 \%, 43.2 \%$, and $31.7 \%$ for DD, ID, and II, respectively, and for AGT M235T, there were MM $28.7 \%$, MT 36.8\%, and TT 34.5\%. In the African continent sub-groups, the percentages were DD $44.6 \%$, ID $41.8 \%$, and II $13.6 \%$ and for the AGT 235 gene, the percentages were MM 8.2\%, MT 19.2\%, and TT $72.5 \%$ in patients with essential hypertension. In the control group, the genotype percentages for ACE I/D were DD $24.0 \%$, ID $43.7 \%$, and II $28.7 \%$.

In AGT M235T, there were MM 11.3\%, MT $17.2 \%$, and $\mathrm{TT} 71.4 \%$. In the gender sub-group, the percentages of ACE I/D in males were DD $29.7 \%$, ID $46.4 \%$, and II $23.8 \%$ and for the AGT 235 gene, the percentages were MM $10.7 \%$, MT $36.1 \%$, and TT $53.3 \%$ in patients with essential hypertension. In the control group, the genotype percentages for ACE I/D in males were DD $29.6 \%$, ID $41.0 \%$, and II $29.4 \%$. In AGT M235T, there were MM 13.7\%, MT 33.1\%, and TT $53.2 \%$. Moreover, in females, there were DD $31.3 \%$, ID $40.2 \%$, and II $28.5 \%$ and for the AGT 235 gene, the percentages were MM 8.7\%, MT 33.1\%, and TT 58.2\% in patients with essential hypertension. In the female control group, the genotype percentages for ACE I/D were DD 23.6\%, ID 41.6\%, and II 24.8\%. In M235T, there were MM 9.7\%, MT 33.4\%, and TT 56.9\%.

Our results found associations between ACE I/D gene polymorphisms and the risk of essential 


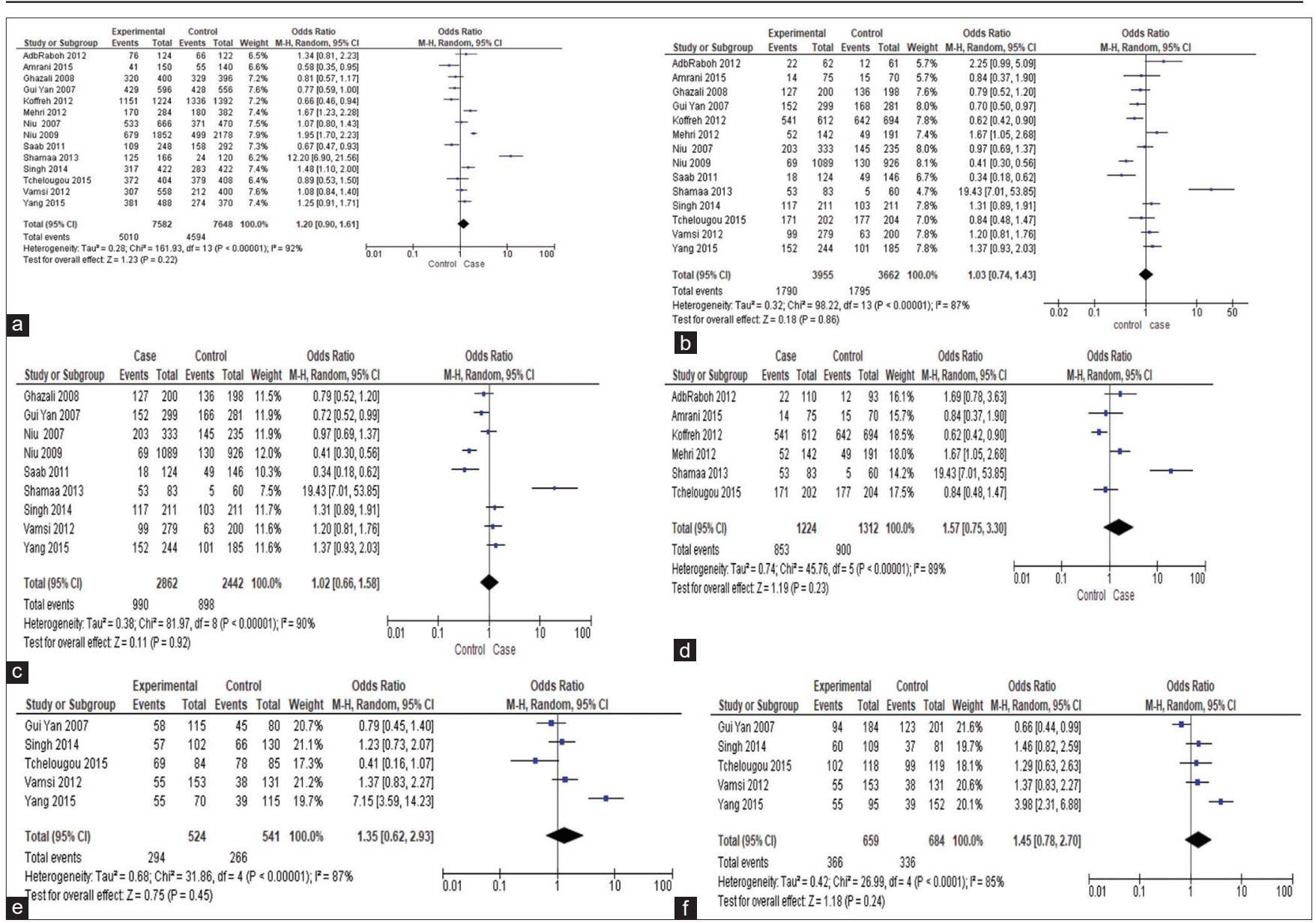

Figure 3: Forest plot for association angiotensinogen M235T gene polymorphism and the risk of essential hypertension: (a) M versus T; (b) TT versus MM+MT; (c) Asian sub-groups (TT vs. MM+MT); (d) African sub-groups (TT vs. MM+MT); (e) Male gender sub-groups (TT vs. MM+MT); and (f) Female gender sub-groups (TT vs. MM+MT)

hypertension in the Asian DD genotype (OR: 95\% $\mathrm{Cl}=1.39$ [1.04-1.87], $\mathrm{p}=0.03$ ) (Figure 2c) and African continent DD genotype sub-group (OR: $95 \% \mathrm{Cl}=2.66$ [1.53-4.62], $p=0.00005)$ (Figure 2d), while in the gender sub-groups, our results did not find any increased risk of essential hypertension in the DD genotype male subgroups (OR: $95 \% \mathrm{Cl}=0.87$ [0.49-1.54], $\mathrm{p}=0.64$ ) nor female sub-groups (OR: $95 \% \mathrm{Cl}=0.94$ [0.33-2.66], $p=0.91)$ (Figure 2e and f).

Oppositely, the results showed some association between the increased risk of essential hypertension and the AGT TT genotype (OR: $95 \% \mathrm{Cl}=1.03$ [0.74-1.43], $p=0.86$ ). Our results also found no association between AGT M235T polymorphisms and the risk of essential hypertension in the Asian gender sub-groups (OR: 95\% $\mathrm{Cl}=1.03$ [0.66-1.58], $\mathrm{p}=0.92$ ), while there were in the African sub-groups (OR: $95 \% \mathrm{Cl}=1.57$ [0.75-3.30], $p=0.23$ ), and AGT M235T in males (OR: $95 \% \mathrm{Cl}=1.35$ [0.62-2.93], $p=0.45$ ), and in females (OR: $95 \% \mathrm{Cl}=1.45$ [0.78-2.70], $p=0.24$ ) (Figure 3).

\section{Sensitivity analysis and publication bias}

The Begg's funnel plot and Egger's regression tests were used to perform analysis of sensitivity and publication bias. In this study, these tests were performed to assess the publication bias in dominant comparison (ACE $I / D=0.1753$ ). This study did not find that the combined OR values changed significantly, which indicated the meta-analysis was stable and reliable. For the funnel plot analysis (Figure 4), the symmetry of each genotype funnel plot displayed no publication bias. The selected studies were considered more representative due to evaluation of the funnel plot symmetry with Begg's and Egger's tests which showed that there was no significant publication bias in the various publications.

\section{Discussion}

Essential hypertension is a complex, multifactorial disease with genetic, and environmental risk factors that contribute to its growing incidence [31], [32], [33]. Hypertension causes significant morbidity and mortality worldwide [34], [33]. Genome-wide association studies have contributed significantly to the present research concerning 
Table 1: The baselines characteristics of the study populations in this meta-analysis

\begin{tabular}{|c|c|c|c|c|c|c|c|c|c|c|c|c|}
\hline \multirow[t]{3}{*}{ Study years } & \multirow[t]{3}{*}{ Country } & \multirow[t]{3}{*}{ HWE } & \multirow[t]{3}{*}{ Method } & \multicolumn{6}{|c|}{ Polymorphism } & \multirow[t]{3}{*}{ Age } & \multirow[t]{3}{*}{ SBP } & \multirow[t]{3}{*}{ DBP } \\
\hline & & & & \multicolumn{3}{|c|}{ ACE I/D } & \multicolumn{3}{|c|}{ AGT M235T } & & & \\
\hline & & & & DD & $\mathrm{DI}$ & II & MM & MT & TT & & & \\
\hline \multirow[t]{2}{*}{ Gui-yan et al. 2006 [4] } & China & Yes & PCR-RFLP & 66 & 142 & 90 & 19 & 127 & 152 & $52.90 \pm 11.43$ & NA & NA \\
\hline & & & & 66 & 113 & 100 & 16 & 94 & 168 & $50.15 \pm 9.64$ & NA & NA \\
\hline \multirow[t]{2}{*}{ Das et al. 2008 [7] } & India & No & PCR & 19 & 4 & 12 & NA & NA & NA & NA & NA & NA \\
\hline & & & & 3 & 18 & 14 & NA & NA & NA & NA & NA & NA \\
\hline \multirow[t]{2}{*}{ Ghazali et al. 2008 [3] } & Malaysia & No & PCR-Sequencing & & NA & NA & 7 & 66 & 127 & $54.8 \pm 6.3$ & $153.5 \pm 21.8$ & $89.2 \pm 13.0$ \\
\hline & & & & & NA & NA & 7 & 55 & 136 & $54.3 \pm 6.4$ & $132.8 \pm 16.8$ & $78.6 \pm 10.2$ \\
\hline \multirow[t]{2}{*}{ Bawazier et al. 2010 [8] } & Indonesia & No & PCR & 1 & 39 & 85 & NA & NA & NA & $45.22 \pm 7.45$ & $149.8 \pm 19.2$ & $95.1 \pm 9.8$ \\
\hline & & & & 4 & 38 & 66 & NA & NA & NA & $41.26 \pm 7.55$ & $105.6 \pm 6.5$ & $68.2 \pm 7.1$ \\
\hline Saab et al. 2011 [9] & Lebanon & Yes & PCR -RFLP & 78 & 37 & 9 & 34 & 72 & 18 & NA & NA & NA \\
\hline & & & & 76 & 58 & 12 & 38 & 59 & 49 & NA & NA & NA \\
\hline Koffreh et al. 2012 [10] & Nigeria & Yes & PCR-RFLP & NA & NA & NA & 4 & 67 & 541 & $51.3 \pm 13.76$ & $161.14 \pm 23.247$ & $93.25 \pm 13.768$ \\
\hline & & & & NA & NA & NA & 2 & 52 & 642 & $31.9 \pm 10.27$ & $116.76 \pm 9.19$ & $72.181 \pm 8.41$ \\
\hline Vamsi et al. 2012 [6] & India & Yes & PCR-RFLP & NA & NA & NA & 70 & 110 & 99 & $55.57 \pm 9.78$ & $160.53 \pm 20.98$ & $98.23 \pm 12.87$ \\
\hline & & & & NA & NA & NA & 53 & 84 & 63 & $47.63 \pm 9.65$ & $120.05 \pm 0.71$ & $80.0 \pm 0.35$ \\
\hline Shamaa et al. 2013 [11] & Egypt & No & PCR-RFLP & NA & NA & NA & 12 & 18 & 53 & $53.5 \pm 7.4$ & $145.28 \pm 7.0$ & $91.2 \pm 2.15$ \\
\hline & & & & NA & NA & NA & 41 & 14 & 5 & $51.3 \pm 8.8$ & $117.33 \pm 4.27$ & $79.17 \pm 3.46$ \\
\hline Singh et al. 2014 [12] & India & Yes & PCR-RFLP & 83 & 88 & 40 & 13 & 81 & 117 & $54.46 \pm 12.65$ & NA & NA \\
\hline & & & & 67 & 93 & 51 & 30 & 78 & 103 & $43.64 \pm 13.87$ & NA & NA \\
\hline Heidarai et al. 2014 [13] & Malaysia & Yes & PCR & 43 & 24 & 4 & NA & NA & NA & $47.22 \pm 11.3$ & $152.0 \pm 13.0$ & NA \\
\hline & & & & 19 & 35 & 18 & NA & NA & NA & $46.92 \pm 12.7$ & $120 \pm 13.3$ & NA \\
\hline Yang et al. 2015 [14] & China & Yes & PCR-RFLP & 41 & 106 & 97 & 14 & 78 & 152 & $61.148 \pm 13.491$ & NA & NA \\
\hline & & & & 30 & 73 & 73 & 13 & 71 & 101 & $59.281 \pm 12.828$ & NA & NA \\
\hline Alsafar et al. 2015 [15] & UAE & Yes & PCR-RFLP & 98 & 135 & 2 & NA & NA & NA & NA & NA & NA \\
\hline & & & & 136 & 163 & 34 & NA & NA & NA & NA & NA & NA \\
\hline Tchelougou et al. 2015 [16] & Africa & Yes & PCR & 135 & 57 & 10 & 2 & 29 & 171 & $51 \pm 10.01$ & $160 \pm 20.66$ & $95 \pm 11.87$ \\
\hline & & & & 73 & 104 & 27 & 3 & 24 & 177 & $49.50 \pm 13.54$ & $120 \pm 11.47$ & $70 \pm 8.24$ \\
\hline Krishnan et al. 2016 [17] & India & Yes & PCR & 81 & 68 & 59 & NA & NA & NA & $43.6 \pm 5.6$ & $151 \pm 9.8$ & $92.56 \pm 8.7$ \\
\hline & & & & 44 & 58 & 118 & NA & NA & NA & $42.78 \pm 5.7$ & $123.34 \pm 1.8$ & $69.89 \pm 5$ \\
\hline Ramu et al. 2017 [18] & India & No & PCR & 127 & 211 & 124 & NA & NA & NA & $45.1 \pm 0.4$ & $153.4 \pm 0.8$ & $97.3 \pm 0.5$ \\
\hline & & & & 101 & 190 & 153 & NA & NA & NA & $47.4 \pm 0.4$ & $117.5 \pm 0.4$ & $78.2 \pm 0.3$ \\
\hline Hussain et al. 2017 [19] & Pakistan & Yes & PCR-RFLP & 18 & 61 & 21 & NA & NA & NA & $52 \pm 11$ & $147 \pm 23$ & $90 \pm 12$ \\
\hline & & & & 15 & 20 & 13 & NA & NA & NA & $47 \pm 8$ & $111 \pm 15$ & $72 \pm 10$ \\
\hline Nawaz et al. 2011 [20] & Pakistan & Yes & PCR & 30 & 41 & 12 & NA & NA & NA & $36.88 \pm 12.38$ & NA & NA \\
\hline & & & & 74 & 143 & 62 & NA & NA & NA & $28.23 \pm 10.45$ & NA & NA \\
\hline Niu et al. 2015 [21] & Kazahtan & Yes & PCR-RFLP & 181 & 184 & 156 & NA & NA & NA & $52.3 \pm 12.4$ & $159.3 \pm 23.6$ & $96.6 \pm 11.8$ \\
\hline & & & & 222 & 187 & 214 & NA & NA & NA & $40.2 \pm 14.3$ & $117.9 \pm 11.6$ & $74.2 \pm 8.2$ \\
\hline Srivastava et al. 2012 [22] & India & Yes & PCR & 138 & 98 & 16 & NA & NA & NA & $51.6 \pm 7.2$ & $145.5 \pm 14.05$ & $120 \pm 3.47$ \\
\hline & & & & 74 & 106 & 42 & NA & NA & NA & $49.7 \pm 10.4$ & $93.6 \pm 8.09$ & $80.49 \pm 2.5$ \\
\hline Jiang 2019 [23] & China & No & PCR & 29 & 108 & 83 & NA & NA & NA & $62.2 \pm 6.1$ & $159.0 \pm 12.9$ & $94.8 \pm 8.5$ \\
\hline & & & & 13 & 112 & 110 & NA & NA & NA & $61.1 \pm 7.7$ & $119.7 \pm 10.1$ & $77.7 \pm 6.8$ \\
\hline AdbRaboh [24] & Egypt & Yes & PCR-RFLP & 34 & 59 & 17 & 8 & 32 & 22 & $45 \pm 8.2$ & $147.8 \pm 13.5$ & $95.6 \pm 6.3$ \\
\hline & & & & 25 & 52 & 16 & 7 & 42 & 12 & $42 \pm 7.3$ & $131.4 \pm 13.4$ & $82 \pm 7.2$ \\
\hline Amrani 2015 [25] & Algeria & Yes & PCR-RFLP & 10 & 40 & 25 & 48 & 13 & 14 & $48 \pm 1.5$ & $154 \pm 10$ & $91 \pm 5$ \\
\hline & & & & 2 & 25 & 43 & 30 & 25 & 15 & $43.1 \pm 1.4$ & $112 \pm 6$ & $72 \pm 7$ \\
\hline Badaruddza 2012 [26] & India & Yes & PCR-RFLP & 18 & 49 & 24 & NA & NA & NA & $52.30 \pm 6.54$ & $147.38 \pm 11.49$ & $92.53 \pm 10.35$ \\
\hline & & & & 20 & 46 & 24 & NA & NA & NA & $52.30 \pm 5.01$ & $131.46 \pm 11.49$ & $79.50 \pm 9.05$ \\
\hline Mehri 2012 [27] & Tunisia & Yes & PCR-RFLP & 57 & 65 & 20 & 23 & 67 & 52 & 61.4 & $161.6 \pm 16.4$ & $100.4 \pm 11.2$ \\
\hline & & & & 34 & 83 & 74 & 60 & 82 & 49 & 60.1 & $126.8 \pm 5.2$ & $82.5 \pm 4.3$ \\
\hline Niu 2007 [28] & Tibet & Yes & PCR-RFLP & NA & NA & NA & 6 & 124 & 203 & $52.27 \pm 11.89$ & $176.89 \pm 15.52$ & $106.97 \pm 11.06$ \\
\hline & & & & NA & NA & NA & 8 & 82 & 145 & $49.63 \pm 10.02$ & $112.60 \pm 12.38$ & $75.03 \pm 10.25$ \\
\hline Niu 2009 [29] & China & Yes & PCR-RFLP & 175 & 451 & 300 & 496 & 361 & 69 & $50.62 \pm 6.58$ & $160.95 \pm 18.07$ & $99.64 \pm 10.59$ \\
\hline & & & & 268 & 474 & 347 & 540 & 419 & 130 & $52.99 \pm 7.50$ & $118.64 \pm 17.66$ & $77.26 \pm 7.83$ \\
\hline Rana 2018 [30] & India & No & PCR & 92 & 69 & 45 & NA & NA & NA & NA & NA & NA \\
\hline & & & & 89 & 93 & 63 & NA & NA & NA & NA & NA & NA \\
\hline
\end{tabular}

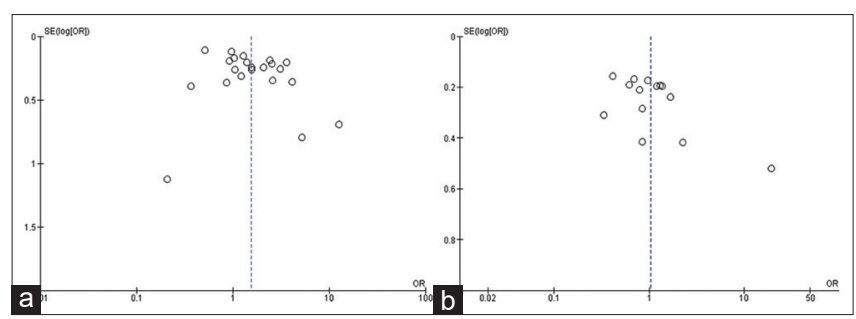

Figure 4: (a) Funnel plot angiotensin-converting enzyme $I / D$ and (b) Funnel plot angiotensinogen M235T

essential hypertension by providing the typology for 100,000 s of single nucleotide polymorphisms through extensive cohorts [35] Results showed that as many as 22 genome-wide scans have identified genetic loci for blood pressure [36] The contribution of genetic types to blood pressure variation is estimated to range from $30 \%$ to $50 \%$. The identification of genotypical variants can enrich our understanding of the etiology of hypertension while also helping to clarify the biochemical and physiological pathways in the disease pathophysiology [32].

The first candidate genes linked to essential hypertension were AGT and ACE [34]. RAS is an important component of blood pressure regulation and associated with hypertension [37], [38]. The classical pathway of the RAS begins with renin cleaving its substrate, AGT, to produce the inactive peptide, angiotensin I, which is then converted to angiotensin II by endothelial ACE. ACE activation of angiotensin II occurs especially in the lungs [39], [40].

Many studies have investigated the relationship between genetic susceptibility and essential hypertension. Research about AGT M235T and ACE I/D showed some association with essential hypertension in Caucasian populations but not in Asians and Africans. We collected 41 papers that investigated 
links between genotypes and essential hypertension. Twenty-seven papers found associations between ACE I/D and the risk of essential hypertension, and eight found no association with hypertension. Six studies showed significant correlations between AGT M235T and essential hypertension while six did not find any association. In the present meta-analysis, our results support the findings of some association of ACE I/D polymorphisms with essential hypertension.

Our meta-analysis results concerning ACE I/D are consistent with the previous studies that found the DD genotype has strong association with essential hypertension. In the sub-group analysis in the Asian population, consistent results were showing that the DD genotype has association with essential hypertension. In addition, in the African sub-groups, the DD genotype was also associated with essential hypertension. However, in the gender sub-group analysis, there was no association in the male or female sub-groups between the DD genotype with essential hypertension. Interestingly, the meta-analysis conducted by Staessen et al. [41] found a significant association between allele $\mathrm{D}$ with hypertension in female and Asian populations.

Jeunemaitre et al. [42] initially identified that AGT M235T was associated with severe hypertension cases compared to controls, and the 235T variant was correlated with increased plasma AGT (20\% higher in $235 \mathrm{~T}$ homozygotes than in $235 \mathrm{M}$ homozygotes). Further findings in Caucasian populations in North America, Europe, Australia, Japan, and Taiwan, and in black populations in the Caribbean, United States, and Africa showed contradictory associations between 235T and hypertension [34]. Our results found no association between the genotype TT with essential hypertension in all analysis and ethnic subgroups. The same result was shown by Ghazali et al. [3] in the Malaysian population. Meanwhile, different results from the meta-analysis conducted by Staessen et al. [43] showed that the T allele was associated with essential hypertension in Caucasian populations but that the association between hypertension and the $\mathrm{T}$ allele may be weaker in black and Asian populations.

Several limitations were noted in the present meta-analysis study. First, since only articles published and written in the English language were retrieved for analysis, this might introduce a potential selection bias. Second, this meta-analysis was not based on individual participant data of each qualified study, such as body mass index, level of physical activity, limiting analysis for gene-to-environment interaction, and age of the participant. Third, the analysis was limited to specific genes for only polymorphism I/D in ACE and AGT M235T genes but other functional genes in the promoter region such as A-240T polymorphisms and AT1R A1166C were not analyzed because of the insufficient data and limited availability. In addition, for allele frequency across studies, the ACE I/D polymorphism exhibited wide divergences, indicating the presence of allele heterogeneity. Fourth, some sub-group analyzes may have been lower for power analysis due to the limited number of studies and small sample sizes involved.

Furthermore, in the present meta-analysis of the included studies, deviations from the HWE were also found. These Hardy-Weinberg inconsistencies might be considered as significant limitations, which might drive some of the false-positive findings. The previous studies might be considered to have a low level of evidence due to these limitations to confer strength to the overall association results.

\section{Conclusion}

The present meta-analysis suggests that angiotensin converting enzyme (ACE I/D) polymorphisms are associated with increased risks of essential hypertension, especially among Asian and African populations. Some studies with different results showed that AGT M235T has no association in Asian and African populations. These findings seem to show that differences in gene pool at different frequencies for each population have different effects on the onset of disease, but the gender-based sub-groups do not differ in expression between men and women. However, in the future, larger sample size studies conducted in different ethnic populations are required to further evaluate our conclusions.

\section{References}

1. Merlo J, Bengtsson-Boström K, Lindblad U, Råstam L, Melander O. Multilevel analysis of systolic blood pressure and ACE gene I/D polymorphism in 438 Swedish families a public health perspective. BMC Med Genet. 2006;7:14. https://doi. org/10.1186/1471-2350-7-14

PMid:16509973

2. Mondry A, Loh M, Liu P, Zhu AL, Nagel M. Polymorphisms of the insertion/deletion ACE and M235T AGT genes and hypertension: Surprising new findings and meta-analysis of data. BMC Nephrol. 2005;6:1-11.

3. Ghazali DM, Rehman A, Rahman AR. Candidate gene polymorphisms and their association with hypertension in Malays. Clin Chim Acta. 2008;388(1-2):46-50. https://doi. org/10.1016/j.cca.2007.10.002

PMid:17977523

4. Gui-Yan W, Yan-Hua W, Qun X, Wei-Jun T, Ming-Ling G, Jian W, et al. Associations between RAS gene polymorphisms, environmental factors and hypertension in Mongolian people. Eur J Epidemiol. 2006;21(4):287-92. https://doi.org/10.1007/ s10654-005-6006-4

PMid:16685579

5. Crews DE, Williams SR. Molecular aspects of blood pressure. Hum Biol. 1999;71(4):475-503. 
PMid:10453099

6. Mohana VU, Swapna N, Surender RS, Vishnupriya S, Padma T. Gender-related association of AGT gene variants (M235T and T174M) with essential hypertension A case-control study. Clin Exp Hypertens. 2012;34(1):38-44. https://doi.org/10.3109/1064 1963.2011.618207

PMid:22148914

7. Das M, Pal S, Ghosh A. Angiotensin converting enzyme gene polymorphism (Insertion/Deletion) and hypertension in adult Asian Indians: A population-based study from Calcutta, India. Hum Biol. 2008;80(3):303-12. https://doi. org/10.3378/1534-6617-80.3.303

PMid:19130799

8. Bawazier LA, Sja'bani M, Haryana SM, Soesatyo $M H$, Sadewa $\mathrm{AH}$. Relationship of angiotensin converting enzyme gene polymorphism and hypertension in Yogyakarta, Indonesia. Acta Med Indones. 2010;42(4):192-8.

PMid:21063039

9. Saab YB, Gard PR, Overall ADJ. The association of hypertension with renin-angiotensin system gene polymorphisms in the Lebanese population. J Renin Angiotensin Aldosterone Syst. 2011;12(4):588-94. https://doi.org/10.1177/1470320311408465 PMid:21628354

10. Kooffreh ME, Anumudu Cl, Akpan EE, Ikpeme EV, Kumar PL. A study of the M235T variant of the angiotensinogen gene and hypertension in a sample population of Calabar and Uyo, Nigeria. Egypt J Med Hum Genet. 2013;14(1):13-9. http://dx.doi. org/10.1016/j.ejmhg.2012.06.007

11. Tripathi G, Dharmani $P$, Khan F, Sharma RK, Pandirikkal V, Agrawal S. High prevalence of ACE DD genotype among north Indian end stage renal disease patients. BMC Nephrol. 2006;7:1-7. https://doi.org/10.1186/1471-2369-7-15

PMid: 17042963

12. Singh KD, Jajodia $A$, Kaur $H$, Kukreti $R$, Karthikeyan $M$. Gender specific association of RAS gene polymorphism with essential hypertension: A case-control study. Biomed Res Int. 2014;2014:538053. https://doi.org/10.1155/2014/538053 PMid:24860821

13. Heidari F, Vasudevan $R$, Mohd Ali SZ, Ismail $P$, Etemad A, Pishva SR, et al. Association of insertion/deletion polymorphism of angiotensin-converting enzyme gene among Malay male hypertensive infjects in response to ACE inhibitors. J Renin Angiotensin Aldosterone Syst. 2015;16(4):872-9. https://doi. org/10.1177/1470320314538878

PMid:25002132

14. Yang YL, Mo YP, He YS, Yang F, Xu Y, Li CC, et al. Correlation between renin-angiotensin system gene polymorphisms and essential hypertension in the Chinese Yi ethnic group. J Renin Angiotensin Aldosterone Syst. 2015;16(4):975-81. https://doi. org/10.1177/1470320315598697 PMid:26283679

15. Alsafar $\mathrm{H}$, Hassoun A, Almazrouei $\mathrm{S}$, Kamal W, Almaini M, Odama $U$, et al. Association of angiotensin converting enzyme insertion-deletion polymorphism with hypertension in emiratis with Type 2 diabetes mellitus and its interaction with obesity status. Dis Markers. 2015;2015:536041. https://doi. org/10.1155/2015/536041

PMid:26491214

16. Tchelougou D, Kologo JK, Karou SD, Yaméogo VN, Bisseye C, Djigma FW, et al. Renin-angiotensin system genes polymorphisms and essential hypertension in Burkina Faso, West Africa. Int J Hypertens. 2015;2015:979631. https://doi. org/10.1155/2015/979631

PMid:26351579

17. Krishnan R, Sekar D, Karunanithy S, Subramanium S.
Association of angiotensin converting enzyme gene insertion/ deletion polymorphism with essential hypertension in south Indian population. Genes Dis. 2016;3(2):159-63. https://doi. org/10.1016/j.gendis.2016.03.001

PMid:30258884

18. Ramu P, Umamaheswaran G, Shewade DG, Swaminathan RP, Dutta TK, Balachander J, et al. Candidate gene polymorphisms of renin angiotensin system and essential hypertension in a South Indian Tamilian population. Int J Hum Genet. 2011;11(1):31-40. https://doi.org/10.1080/09723757.2011.11886120

19. Hussain M, Awan FR, Gujjar A, Hafeez S, Islam M. A case control association study of ACE gene polymorphism (I/D) with hypertension in Punjabi population from Faisalabad, Pakistan. Clin Exp Hypertens. 2018;40(2):186-91. https://doi.org/10.1080 /10641963.2017.1356842

PMid:29058472

20. Nawaz SK, Hasnain S. Effect of ACE polymorphisms on the association between noise and hypertension in a Pakistani population. J Renin Angiotensin Aldosterone Syst. 2011;12(4):516-20. https://doi.org/10.1177/1470320310395799 PMid:21436208

21. Niu S, Zhang B, Zhang K, Zhu P, Li J, Sun Y, et al. Synergistic effects of gene polymorphisms of the renin-angiotensinaldosterone system on essential hypertension in Kazakhs in Xinjiang. Clin Exp Hypertens. 2016;38(1):63-70. https://doi.org/ 10.3109/10641963.2015.1060985

PMid:26305278

22. Srivastava K, Sundriyal R, Meena PC, Bhatia J, Narang R, Saluja D. Association of angiotensin converting enzyme (insertion/deletion) gene polymorphism with essential hypertension in Northern Indian subjects. Genet Test Mol Biomarkers. 2012;16(3):174-7. https://doi.org/10.1089/ gtmb.2011.0155 PMid:22103580

23. Jiang $\mathrm{X}$, Sheng $\mathrm{H}$, Li J, Xun $\mathrm{P}$, Cheng $\mathrm{Y}$, Huang J, et al. Association between renin-angiotensin system gene polymorphism and essential hypertension: A communitybased study. J Hum Hypertens. 2009;23(3):176-81. https://doi. org/10.1038/jhh.2008.123

PMid: 18830250

24. AbdRaboh NR, Hemimi NS, Louka ML, El Bakrt S. Association of angiotensin converting enzyme insertion/ deletion and angiotensin T235 polymorphism with risk of essential hypertension in Egyptian patients. Int J Cancer Res. 2012;8(3):69-82. https://doi.org/10.3923/ijcr.2012.69.82

25. Amrani A, Hamed MB, Talebbendiab FM. Association study between some renin-angiotensin system gene variants and essential hypertension in a sample of Algerian population: Case control study. Ann Biol Clin (Paris). 2015;73(5):557-63. https:// doi.org/10.1684/abc.2015.1069 PMid:26489814

26. Badaruddoza, Sudhir N. No evidence for association between ACE gene insertion (I)/deletion (D) polymorphism and hypertension in north Indian Punjabi population. Int $\mathrm{J}$ Hum Genet. 2012;12(3):177-83. https://doi.org/10.1080/09723757.2 012.11886180

27. Mehri S, Mahjoub S, Hammami S, Zaroui A, Frih A, Betbout F, et al. Renin-angiotensin system polymorphisms about hypertension status and obesity in a Tunisian population. Mol Biol Rep. 2012;39(4):4059-65. https://doi.org/10.1007/ s11033-011-1187-2

PMid:21779803

28. Niu W, Qi Y, Cen W, Cui C, Zhuoma C. Genetic Polymorphisms of Angiotensinogen and. Hypertens Res. 2007;30(11):1129-37. https://doi.org/10.1291/hypres.30.1129

PMid:18250562 
29. Niu W, Qi Y, Hou S, Zhai X, Zhou W, Qiu C. Haplotype-based association of the renin-angiotensin-aldosterone system genes polymorphisms with essential hypertension among Han Chinese: The Fangshan study. J Hypertens. 2009;27(7):1384-91. https:// doi.org/10.1097/HJH.0b013e32832b7e0d PMid:19412130

30. Rana G, Yadav S, Joshi S, Saraswathy KN. Association of DD genotype of angiotensin-converting enzyme gene (I/D) polymorphism with hypertension among a North Indian population. J Community Genet. 2018;9(1):51-5. https://doi. org/10.1007/s12687-017-0321-9

PMid:28770441

31. Butler MG. Genetics of hypertension current status. J Med Liban. 2010;58(3):175-8.

PMid:21462849

32. Tanira MO, Al Balushi KA. Genetic variations related to hypertension: A review. J Hum Hypertens. 2005;19(1):7-19. PMid:15361889

33. Siyad AR. Hypertension. Hygeia J D Med. 2011;3(1):1-16.

34. Dickson ME, Sigmund CD. Genetic basis of hypertension: Revisiting angiotensinogen. Hypertension. 2006;48(1):14-20. https://doi.org/10.1161/01.HYP.0000227932.13687.60 PMid:16754793

35. Russo A, Di Gaetano C, Cugliari G, Matullo G. Advances in the genetics of hypertension: The effect of rare variants. Int $\mathrm{J} \mathrm{Mol}$ Sci. 2018;19(3):688. https://doi.org/10.3390/ijms19030688 PMid:29495593

36. Hopkins PN, Hunt SC. Genetics of hypertension. Genet Med. 2003;5(6):413-29. https://doi.org/10.1097/01. gim.0000096375.88710.a6 PMid:14614392

37. Heidari F, Vasudevan R, Mohd Ali SZ, Ismail P, Arkani M. RAS genetic variants in interaction with ACE inhibitors drugs influences essential hypertension control. Arch Med Res. 2017;48(1):88-95. https://doi.org/10.1016/j.arcmed.2017.03.003

PMid:28577874

38. Ismail M, Akhtar N, Nasir M, Firasat S, Ayub Q, Khaliq S. Association between the angiotensin-converting enzyme gene insertion/deletion polymorphism and essential hypertension in young Pakistani patients. J Biochem Mol Biol. 2004;37(5):552-5. https://doi.org/10.5483/bmbrep.2004.37.5.552

PMid: 15479618

39. Naomi A, Fisher DL. Overview of the Renin-angiotensin System; 2019. p. 1-25. Available from: https://www.uptodate.com [Last accessed on 2021 Apr 20].

40. Seidel E, Scholl UI. Genetic mechanisms of human hypertension and their implications for blood pressure physiology. Physiol Genomics. 2017;49(11):630-52. https://doi.org/10.1152/ physiolgenomics.00032.2017

41. Staessen JA, Wang JG, Ginocchio G, Petrov V, Saavedra AP, Soubrier $\mathrm{F}$, et al. The deletion/insertion polymorphism of the angiotensin converting enzyme gene and cardiovascularrenal risk. J Hypertens. 1997;15(12 Pt 2):1579-92. https://doi. org/10.1097/00004872-199715120-00059 PMid:9488209

42. Jeunemaitre $X$, Lifton RP, Charru A, Hunt SC, Hopkins PN, Williama RR, et al. Molecular basis of human hypertension: Role of angiotensinogen. Cell. 1992;71(1):169-80. https://doi. org/10.1016/0092-8674(92)90275-h

PMid:1394429

43. Staessen JA, Kuznetsova T, Wang JG, Emelianov D, Vlietinck R, Fagard R. M235T angiotensinogen gene polymorphism and cardiovascular renal risk. J Hypertens. 1999;17(1):9-17. https:// doi.org/10.1097/00004872-199917010-00003

PMid:10100088 